\title{
Telemedicina en cirugía maxilofacial
}

\section{Telemedicine in maxillofacial surgery}

\author{
J. Herce López1, C. Salazar Fernández², Á. Rollón Mayordomo33, D. Moreno Ramírez4, F. Garrachón\$, \\ P. Serrano Moya', J.M. Pérez Sánchez ${ }^{7}$
}

Resumen: En nuestra especialidad el cáncer oral, debido a su elevada mortalidad, así como otras patologías de menor gravedad pero de gran morbilidad y presión asistencial como la cirugía oral y la patología de la articulación temporomandibular, nos obligan a minimizar las demoras optimizando los recursos de que disponemos. Dentro de estos recursos, la aplicación de las nuevas tecnologías a la medicina se está imponiendo en todas las especialidades. Entre estas nuevas tecnologías, está adquiriendo un papel protagonista la telemedicina. Creemos que ésta nos puede servir como sistema óptimo y eficaz de cribado y derivación de pacientes desde atención primaria (AP) hasta el nivel hospitalario. En el presente artículo describimos todos los detalles relacionados con el desarrollo, la utilización y las ventajas de una teleconsulta como herramienta integrante de una unidad de gestión clínica para el proceso diagnóstico y terapéutico de la patología de la articulación temporomandibular valorando de esta forma su aplicabilidad en otros ámbitos de la cirugía oral y maxilofacial.

Palabras clave: Telemedicina; Cirugía Maxilofacial; Nuevas Tecnologías.

Recibido: 09.07.07

Aceptado: 07.03 .08
Abstract: There is a group of pathologies that tolerate little delay and require optimal use of the resources available to us in our daily work as oral and maxillofacial surgeons. For instance, oral cancer has a high mortality and other pathologies, which otherwise are not serious, have a high morbidity and care burden, e.g., oral surgery and temporomandibular joint dysfunction.

Among these resources, the use of new technologies in medicine has become routine practice in every specialty. Among these technologies, telemedicine is becoming prominent. We believe that telemedicine could be an optimal system for screening patients for referral from primary care to hospitals. The development, use, and advantages of teleconsultation as a tool used in a clinical management unit for the diagnosis and treatment of temporomandibular joint disorders is described. The potential use of teleconsultation in other fields of oral and maxillofacial surgery is evaluated.

Key words: Telemedicine; Maxillofacial surgery; New technology.

1 Médico Residente.

2 Facultativo Especialista de Área.

3 Jefe de Sección.

4 Facultativo Especialista de Área, Unidad de Lesiones Pigmentadas. Departamento de Dermatología.

5 Director Área Quirúrgica.

6 Directora Gerente.

7 Jefe de Servicio.

Servicio de Cirugía Oral, Maxilofacial y Estomatología.

Hospital Universitario Virgen Macarena de Sevilla, España

\section{Correspondencia:}

Javier Herce López

Calle Alcalde Manuel Camino Míguez №4

41960 Gines. Sevilla, España

Email: javiherce@yahoo.es 


\section{Introducción}

Los nuevos sistemas de gestión clínica por procesos asistenciales tienden a reducir al mínimo los tiempos de demora diagnóstica y terapéutica en numerosas patologías. En nuestra especialidad el cáncer oral, debido a su elevada mortalidad (50\% a los 5 años) ${ }^{1}$ así como otras patologías de menor gravedad pero de gran morbilidad y presión asistencial, nos obligan a minimizar las demoras optimizando los recursos de que disponemos. Dentro de estos recursos, la aplicación de las nuevas tecnologías a la medicina se está imponiendo en todas las especialidades.

"La telecomunicación moderna promete la resolución de uno de los problemas más apremiantes para la sociedad, compartir un número limitado de recursos entre un elevado número de usuarios, entendiendo como recursos todos los aparatos, servicios y, especialmente, conocimientos" ${ }^{2}$. Con esta filosofía surgieron en todo el mundo experiencias de telemedicina. Desde 1996 en que se publica el primer trabajo sobre telemedicina en cirugía maxilofacial, ${ }^{3}$ hasta febrero de 2007, han sido sólo 13 los artículos que hemos encontrados en PUBMED con las palabras claves telemedicine y maxiIlofacial surgery. La mayoría de ellos utilizando sistemas de telemedicina en directo o sincrónica como la videoconferencia.4-7 Sin embargo, los buenos resultados de la teledermatología en nuestra área hospitalaria, ${ }^{8}$ nos hacen pensar en la telemedicina como sistema de cribado y derivación de pacientes desde atención primaria (AP) hasta el nivel hospitalario eficaz no sólo en patologías de un gran impacto por su gravedad, como el cáncer oral, sino en otras que por su elevada prevalencia suponen una carga asistencial importante (patología de las inclusiones dentarias y patología de la articulación temporomandibular).

Aunque el proyecto de instauración de telemedicina en nuestro servicio engloba tanto las lesiones precancerosas y el cáncer oral, como la patología de las inclusiones dentarias, y la patología de la articulación temporomandibular (ATM), en un primer periodo piloto lo realizaremos con los trastornos temporomandibulares (TTM).

Describimos en este artículo todos los detalles relacionados con el desarrollo, la utilización y las ventajas de una teleconsulta como herramienta integrante de una unidad de gestión clínica para el proceso diagnóstico y terapéutico de la patología de la articulación temporomandibular, valorando de esta forma su aplicabilidad en otros ámbitos de la cirugía oral y maxilofacial.

\section{Justificacion de la telemedicina en cirugía maxilofacial. Objetivos de la teleconsulta de ATM}

Como cualquier iniciativa que pretenda mejorar el sistema existente, exige una revisión de la situación previa de la que se pretende partir, hemos analizado los datos epidemiológicos de la patología de la ATM de la base de datos de nuestro servicio en el 2006. De los 1758 pacientes atendidos como primera visita en consultas externas de Cirugía Maxilofacial del HUV Macarena de Sevilla en el año 2006, 390 (22,18\%) consultaron por disfunción de la ATM. De estos 390, sólo 127 (32,56\%) fueron diagnosticados como Síndrome de Disfunción Temporomandibular (SDTM) en estadios IV ó V de Wil-

\section{Introduction}

New systems of clinical management by intervention processes tend to minimize diagnostic and therapeutic delay in many pathologies. In our specialty, oral cancer, due to its high mortality (5-year survival 50\%), ${ }^{1}$ and other, less serious pathologies that have a high morbidity and care burden, demand that we reduce delay by optimizing available resources. Among these resources, new technologies in medicine are coming into use in every specialty.

"Modern telecommunications promise a solution for one of the most pressing problems of society, how a limited number of resources can be shared by a large number of users, understanding as resources all instruments, services and, especially, knowledge."2 This philosophy has guided the introduction of telemedicine systems throughout the world. Since 1996, when the first study on telemedicine in maxillofacial surgery was published, ${ }^{3}$ to February 2007, only 13 articles are found in PUBMED with the key words telemedicine and maxillofacial surgery. Most of them describe the use of telemedicine systems to broadcast directly or synchronously, as in videoconferences. ${ }^{4-7}$ However, the good results obtained with teledermatology in our hospital area 8 suggest that telemedicine can be used as a system for screening and referring patients from primary care to hospitals, not only for pathologies whose impact is due to their seriousness, such as oral cancer, but also in pathologies others that represent a care burden due to their high prevalence (dental inclusion and temporomandibular joint pathology).

Although the project for introducing telemedicine in our department includes precancerous lesions and oral cancer, as well as dental impaction and temporomandibular joint (TMI) pathology, the pilot study will be conducted with temporomandibular pathology (TMDS).

We describe in this article the details of the development, use, and advantages of teleconsultation as an integral tool of a clinical management unit for the diagnostic and therapeutic management of temporomandibular joint pathology. We expect to be able to evaluate its applicability to other areas of oral and maxillofacial surgery.

Justification of telemedicine in maxillofacial surgery. Objectives of TMJ teleconsultation

As with any initiative that is proposed as an improvement over the existing system, the baseline situation must be assessed. We analyzed the epidemiologic data of TMJ pathology in the department database in 2006. Of 1758 patients with an index visit in the maxillofacial surgery outpatient clinic of HUV Macarena of Sevilla in 2006, 390 (22.18\%) consulted for TMJ dysfunction. Of 390 patients, only 127 (32.56\%) were diagnosed as temporomandibular dysfunction syndrome (TMDS), Wilkes stage IV or V, or presented some other TMJ pathology that required maxillofa- 
kes, o presentaron alguna otra patología de la ATM que precisó tratamiento por cirugía maxilofacial (hiperplasia de cóndilo, quistes, tumores, etc). Los $263(67,44 \%)$ pacientes restantes presentaron o bien patología primaria muscular (Sd. Miofascial, fundamentalmente) o SDTM en estadios I, II y III de Wilkes, por lo que podían haber sido correctamente asistidos en su centro de atención primaria (AP) correspondiente con lo que, hubiésemos evitado desplazamientos y costes innecesarios, que teniendo en cuenta la extensión geográfica de nuestra área hospitalaria con poblaciones a más de $90 \mathrm{~km}$ de distancia, son de una cuantía considerable.

Por tanto, la búsqueda de un sistema de selección de pacientes en atención primaria tributarios de una asistencia especializada en un periodo de tiempo adecuado, se convierte en una prioridad dentro de nuestra unidad clínica.

Por ello, nos planteamos los siguientes objetivos de la teleconsulta de ATM:

1. Dar una asistencia sanitaria especializada adecuada y eficiente en atención primaria en el 60-70\% de los pacientes que presentan trastornos temporomandibulares (TTM).

2. Selección de pacientes con TTM subsidiarios de tratamiento por cirugía maxilofacial.

3. Reducción de la demora de asistencia especializada en pacientes con TTM.

4. Disminución de la carga asistencial en consultas externas de nuestra especialidad y mejora en la atención de otras patologías (oncología, cirugía oral, etc.).

5. Fomento de la relación atención primaria-especializada aportando nuevas vías de comunicación con nuestra unidad.

6. Valoración inicial de la aplicabilidad de la teleconsulta en otros ámbitos de la cirugía maxilofacial (lesiones precancerosas, cirugía oral, etc.), actuando la teleconsulta para los pacientes con disfunción de ATM como pilotaje en la introducción de ésta en otros ámbitos de nuestra especialidad.

7. Realizar una función de investigación en el campo de la ATM permitiendo conocer su epidemiología, protocolo diagnóstico y terapéutico de esta patología en nuestra área sanitaria.

8. Aplicar el desarrollo de las nuevas tecnologías al campo de la cirugía maxilofacial.

\section{Fundamentos técnicos de la teleconsulta}

La base técnica sobre las que se fundamenta la teleconsulta de ATM es un sistema de telemedicina a tiempo diferido o asincrónico, conocido también con el término store-forward. Esta denominación hace referencia a que la información (los datos de la historia clínica y la imagen digital) se recoge y se almacena en una primera fase y posteriormente se envía mediante correo electrónico al cirujano maxilofacial responsable de la teleconsulta (Fig. 1).

Esta metodología tiene varias ventajas sobre los sistemas de telemedicina en tiempo real; la más importante es que no es necesario que el paciente, el consultor y el teleconsultado coincidan en tiempo y espacio, además se evitan las dificultades tecnológicas y de organización de una consulta mediante videoconferencia, igualmente permite la evaluación de un mayor número de pacient es cial surgery (condylar hyperplasia, cysts, tumors, etc). The remaining 263 (67.44\%) patients had primary muscular pathology (fundamentally myofascial syndrome) or TMDS, Wilkes stages I, II and III, which is why they could be correctly managed in the primary care center, thus avoiding unnecessary travel and expense. In view of the fact that our hospital district includes populations located more than 50 miles $(90 \mathrm{~km}$ ) away, this is no small matter.

Therefore, the search for a patient selection system in primary care that facilitates specialist care within a reasonable time period is a priority in our clinical unit.

For that reason, we established the following objectives for TMJ teleconsultation:

1. To provide adequate and efficient specialist medical opinions in primary care to $60-70 \%$ of the patients with temporomandibular pathology (TMDS).

2. Selection of patients with TMDS requiring maxillofacial surgery.

3. Reduction of the delay in providing specialist care to patients with TMDS.

4. Reduction of the care burden of the outpatient clinics of our specialty and improved care for other pathologies (oncology, oral surgery, etc).

5. Encouragement of the relation between the primary care physician and specialist by providing new routes of communication with our unit.

6. Preliminary assessment of the use of teleconsultation in other maxillofacial surgery settings (precancerous lesions, oral surgery, etc). Teleconsultation for patients with TMJ dysfunction is being used as a pilot program for introducing this tool in other areas of our specialty.

7. To conduct research in the field of TMDS to investigate the epidemiology and diagnostic and therapeutic protocol of this pathology in our health area.

8. To apply the development of new technologies to the field of maxillofacial surgery.

\section{Technical fundamentals of teleconsultation}

The technical platform of TMJ teleconsultation is a deferred, or asynchronous, telemedicine system, also known as a storeforward system. This designation refers to the fact that the information (clinical history data and digital image) is first compiled and stored and then sent by electronic mail to the maxillofacial surgeon responsible for teleconsultation (Fig. 1).

This methodology has several advantages over real-time telemedicine systems. Most importantly, it is not necessary for the patient, primary care physician, and teleconsulted specialist to coincide in time and space. In addition, the technological and organizational difficulties of a consultation by videoconference are avoided. It also allows more patients to be evaluated per session and reduces costs by leveraging existing resources like electronic mail and radiology digitalization in our hospital. 
por sesión y el bajo coste que supone la utilización de elementos ya existentes, como el correo electrónico y la próxima digitalización de la radiología en nuestro hospital.

\section{Funcionamiento de la teleconsulta. Circuito de derivación}

Con la protocolización de todas las fases de la teleconsulta conseguiremos una forma de trabajo uniforme y estandarizada en todos los centros usuarios de este servicio.

- $1^{a}$ fase. El paciente que consulte a su centro de atención primaria por disfunción de la ATM, será valorado por su odonto-estomatólogo, quién deberá rellenar el cuestionario que para tal efecto se ha elaborado (Tabla 1). Dicho cuestionario representa el soporte físico mediante el cual se transmite la información clínica del paciente. Ha sido diseñado con los objetivos de simplicidad, accesibilidad y familiaridad de uso para cualquier facultativo y a partir de una información mínima necesaria que nos permita, junto con las imágenes radiográficas, diagnosticar correctamente a los pacientes. En esta primera visita además de la valoración clínica, el facultativo solicitará una ortopantomografía y una tomografía sagital de ambas ATM con boca abierta y cerrada (radiografía en proyección de Schüller en su defecto) y entregará al paciente un documento donde se detallan las medidas que deberá realizar hasta su próxima visita (dieta blanda, evitar excitantes y factores desencadenantes y tomar tila o valeriana 2-3 veces al día). El cuestionario clínico será enviado por correo electrónico encriptado a través de la Red Intranet Corporativa del Sistema Andaluz de Salud (SAS) a la dirección de la Unidad de ATM. Dicho cuestionario irá encabezado por el Número Único de Historia de Salud de Andalucía (NUHSA), de tal forma se evita la transmisión de datos del paciente a través de la red.

- $2^{a}$ fase. Dicho formulario, junto con las pruebas radiológicas, serán evaluados en la consulta de ATM por los dos cirujanos maxilofaciales responsables. Tras la evaluación de la información clínicoradiológica del paciente, el cirujano maxilofacial procederá a la redacción y envío por correo electrónico de un informe diagnóstico y terapéutico al centro de salud solicitante en un plazo de $72 \mathrm{~h}$. El soporte físico será también una página del procesador de texto Word, encabezada por el NUHSA (Tabla 2).

- $\quad 3^{a}$ fase. El paciente será citado en su centro de salud donde será informado por el médico solicitante de la teleconsulta del resultado del informe y de los pasos a seguir a partir de ese momento, bien completando su tratamiento en atención primaria o siendo derivado a la consulta de ATM de nuestro servicio si fuera preciso.

- $4^{a}$ fase. Aquellos pacientes que precisen ser derivados a la Consulta física de ATM en atención especializada llevarán adjunto
How teleconsultation
works. Referral circuit

By conducting each phase of teleconsultation according to protocol, we unify and standardize the operation of all centers using this service.

- Phase 1: The patient who is seen in the primary care center for TMJ dysfunction is assessed by the odonto-stomatologist, who completes the questionnaire prepared for this purpose (Table 1). This questionnaire is the physical substrate for transmitting the patient's clinical information. It has been designed to be simple, accessible, and familiar for use by for any professional. It provides us with the necessary minimum information and radiographic images to correctly diagnose patients. In this initial visit, the primary care physician not only will clinically evaluate the patient, but will order an orthopantomogram and sagittal tomography of both TM/s with the mouth open and closed (or a Schüller projection radiograph). The physician will give the patient written instructions on the measures that the patient should follow until the next visit (soft diet, avoidance of stimulants and trigger factors, and to drink limeblossom or valerian infusions 2-3 times a day). The clinical questionnaire is sent by encrypted electronic mail through the Corporate Intranet Network of the Andalusian Health System (SAS, Spanish initials) to the address of the TMJ Unit. This questionnaire will be labeled with the Andalusia Unique Medical Record Number (NUHSA, Spanish initials) to avoid transmitting the patient's personal data through the network.

- Phase 2. This form and the radiologic studies will be evaluated in the TMJ Unit by the two maxillofacial surgeons responsible. After evaluating the patient's clinical and radiological information, the maxillofacial surgeon will write a diagnostic and therapeutic report and send it by electronic mail to the consulting primary care center within $72 \mathrm{~h}$. Part of the physical material will be a Word template labeled with the NUHSA (Table 2).

- Phase 3. The patient will be scheduled for an appointment at the primary care center to be informed of the results of the report by the physician who requested the teleconsultation. The patient will be given instructions about the next steps to be taken, which will either be to complete treatment in primary care or to continue treatment with our department's TMJ Unit.

- Phase 4. Patients who are referred to the physical TMJ clinic for specialized care will take the report for an appointment within a maximum term of 7-15 days. 
Tabla 1. Formulario de petición de teleconsulta

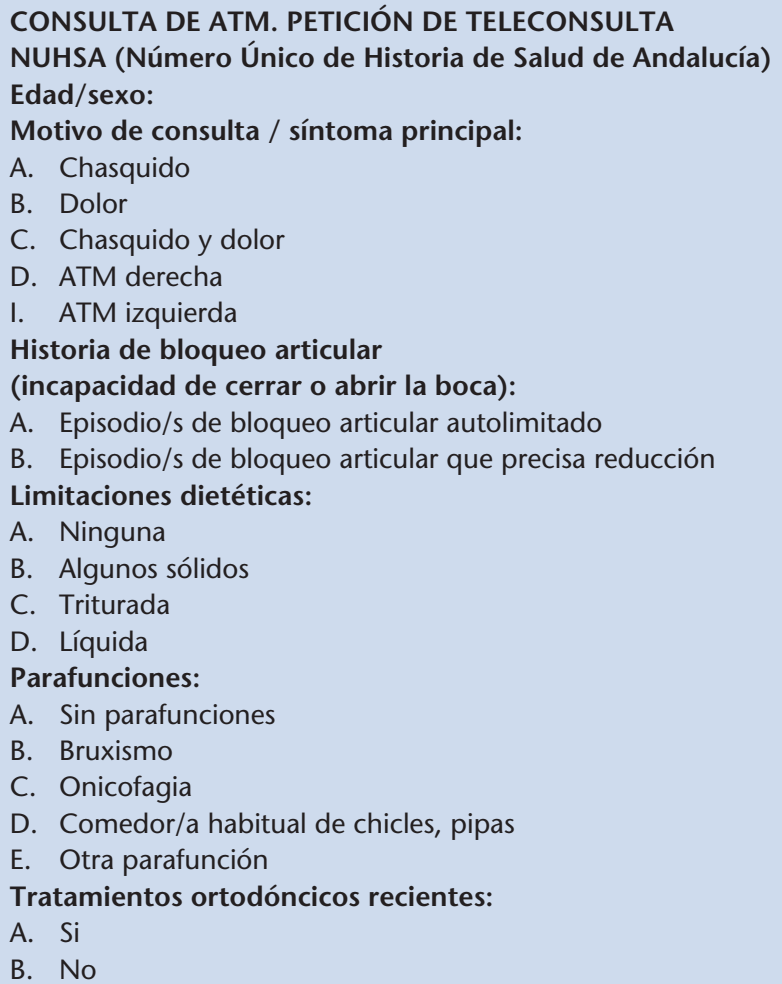

\section{Antecedentes de traumatismos faciales:}

A. $\mathrm{Si}$

B. No

Antecedentes de patología articular:

$\begin{array}{ll}\text { A. } & \text { Si } \\ \text { B. No }\end{array}$

Faltan más de 1 molar por hemiarcada o existe maloclusión evidente:

A. $\mathrm{Si}$

B. No

Limitación de la apertura oral:

A. $\mathrm{Si}$

B. No

Palpación de la ATM:

A. Dolor

B. Chasquido

D. Derecha.

I. Izquierda.

Dolor musculatura masticatoria:

A. $\mathrm{Si}$

B. No

D. Derecha

I. Izquierda

Dolor articular: (EAV 0-10):

Juicio clínico:

A. Síndrome disfunción temporomandibular.

B. Síndrome miofascial.

Unidad de Patología de la Articulación Temporomandibular. Servicio de Cirugía Oral y Maxilofacial y Estomatología. HU Virgen Macarena de Sevilla. España

Table 1. Teleconsultation request form

\section{TMI UNIT. TELECONSULTATION REQUEST} NUHSA (Andalusia Unique Medical Record Number) Age/sex:

Motive of consultation / primary symptom:

A. Crepitation

B. Pain

C. Crepitation and pain

D. Right TMJ

I. Left TMJ

History of lockjaw (inability to open or close the mouth):

A. Self-limited episode/s of lockjaw

B. Episode/s of lockjaw requiring reduction

Dietary restrictions:

A. None

B. Some solids

C. Ground food

D. Liquid

Parafunctions:

A. No parafunctions

B. Bruxism

C. Nail-biting

D. Routine gum chewing, snack eating

E. Another parafunction Recent orthodontic treatments:
A. Yes

B. No

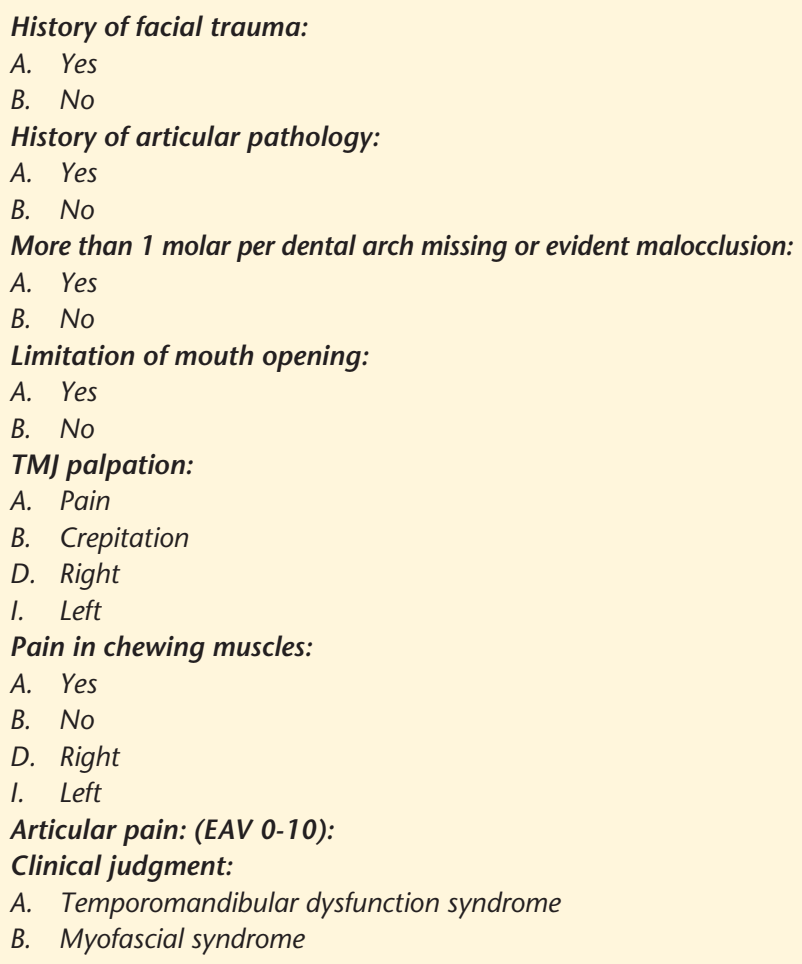

A. Yes

B. No

History of articular pathology:

More than 1 molar per dental arch missing or evident malocclusion:

A. Yes

Limitation of mouth opening:

TMJ palpation:

A. Pain

D. Right

I. Left

Pain in chewing muscles:

D. Right

I. Left

Articular pain: (EAV 0-10):

A. Temporomandibular
$B$. Myofascial syndrome

Temporomandibularjoint Pathology Unit Oral and Maxillofacial. Surgery and Stomatology Department HU Virgen Macarena, Sevilla. España 
al informe, la cita para dicha consulta en un plazo máximo de 7-15 días.

La puesta en marcha de la Unidad de ATM y la teleconsulta va a suponer una transformación del circuito asistencial de este tipo de patología (Fig. 2).

El flujo de comunicación directa entre atención primaria y el servicio de Cirugía Oral y Maxilofacial mediante la teleconsulta permitirá al paciente disponer de una opinión especializada de su patología en un plazo máximo de 4 semanas (este periodo se vería acortado reduciendo la demora de las pruebas radiológicas que actualmente está en torno a los 20 días), frente a las 8 semanas de demora del circuito tradicional (base de datos del Servicio de Cirugía Maxilofacial del HUV Macarena), e incluso resolver su problema sin necesidad de desplazamiento, en los casos en los que su patología pueda tratarse en su dentro de salud.

La selección de pacientes mediante la teleconsulta permite igualmente atender en el hospital a aquellos pacientes que precisen tratamiento especializado de la patología articular en un plazo máximo de 30 días. De esta forma se conseguirá que todos los pacientes que consulten en atención primaria por disfunción de la ATM sean valorados por un cirujano maxilofacial, aunque sólo tendrán que desplazarse hasta el hospital aquellos que precisen tratamiento por nuestra especialidad.

\section{Criterios de selección de pacientes con patología de la ATM a tratar por cirugía maxilofacial}

Los criterios de selección de pacientes que son subsidiarios de tratamiento en atención especializada (consulta física de ATM) son:

1. Paciente con imagen radiográfica sugestiva de patología ósea en alguna de las superficies articulares (tumoración ósea, hiperplasia de cóndilo, malformación, fractura, anquilosis, etc.) independientemente de la clínica que presente.

2. Pacientes con hallazgos radiológicos sugestivos de artrosis que se acompañen de sintomatología clínica importante (limitación de la apertura oral, dolor crónico e historia de bloqueos que precisaron reducción).

3. Pacientes con patología articular sin criterios para tratamiento en atención especializada inicialmente y que no hayan mejo-
Temporomandibular Joint Pathology Unit and Stomatology Department H.U. Virgen Macarena, Sevilla NUHSA:

Summarized clinical report de a las ____ horas a y Maxilofacial y Estomatología H.U. Virgen Macarena de Sevilla NUHSA:

Resumen de la $\mathrm{H}^{\mathrm{a}}$ clínica

Medidas terapéuticas:

*(En caso de cumplir criterios de selección):

Clinical judgment:

Theric m

*(If screening criteria are met): of __ at _ : - time to the TMJ Unit Virgen Macarena of Sevilla (1st floor of Hospital, Stomatology clinic 5)
Development of the TMJ Unit and teleconsultation will transform the circuit of care for this type of pathology (Fig. 2).

The flow of direct communication between primary care and the oral and maxillofacial surgery department as a result of teleconsultation will allow the patient to obtained a specialist's opinion within a maximum term of 4 weeks (a period that could be shortened by reducing the delay in radiologic studies, which currently take about 20 days), as opposed to 8 weeks in the traditional circuit (database of the Maxillofacial Surgery Department, HUV Macarena). The patient's problem may even be solved without any need for travel in cases in which the pathology can be treated in the local primary care clinic.

Screening patients by teleconsultation also allows us to schedule hospital care for patients who require specialized treatment of their articular pathology within a maximum period of 30 days. Consequently, all patients seen in primary care for TMJ dysfunction are assessed by a maxillofacial surgeon, but only patients who required treatment by a specialist have to come to the hospital.

\section{Criteria for screening patients with TMJ pathology for referral for treatment by maxillofacial surgery}

The criteria for screening patients who require the care of a specialist (physical TMJ Unit) are:

1. Patient with a radiographic image suggestive of bone pathology that affects articular surfaces (bone tumor, condylar hyperplasia, malformation, fracture, ankylosis, or other), regardless of the clinical manifestations.

2. Patients with radiologic findings suggestive of arthrosis and intense clinical symptoms (restricted mouth opening, chronic pain, and history of lockjaw requiring reduction). 
rado después de realizar el tratamiento durante 1 año (según protocolo actual del Servicio de Cirugía Oral y Maxilofacial-Estomatología del HUV Macarena de Sevilla).

\section{Recursos humanos, materiales, tecnológicos y organización del trabajo}

La unidad queda constituida por 2 cirujanos maxilofaciales con dedicación parcial que hacen las funciones asistenciales, de gestión y formativas relacionadas con dicha consulta.

Será necesario una Consulta física en Atención especializada con un terminal de PC de alta capacidad (softwa-

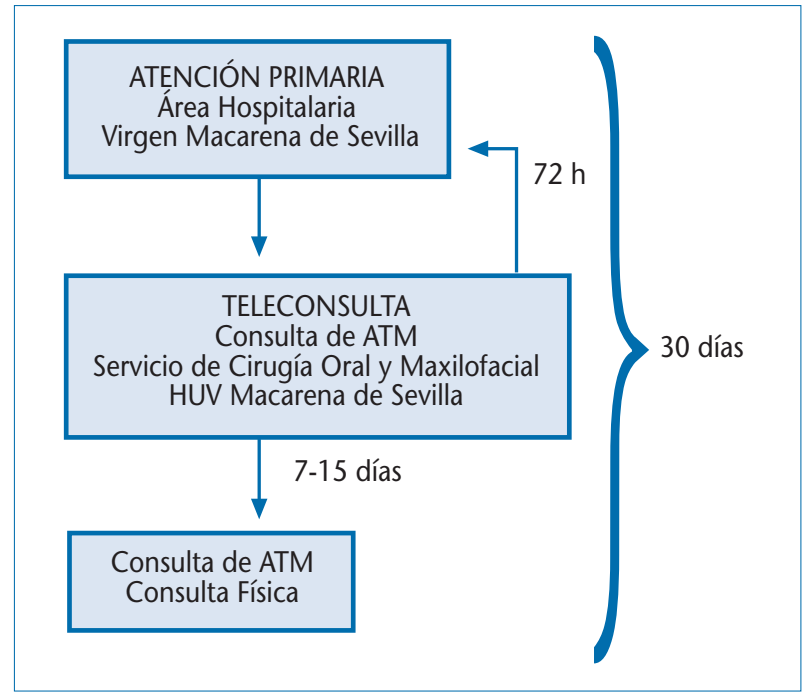

Figura 2. Circuito de derivación. Figure 2. Referral circuit.
3. Patients with articular pathology who do not meet criteria for initial specialist treatment, but do not improve after receiving treatment for 1 year (according to the current protocol of the Oral and Maxillofacial SurgeryStomatology Department, HUV Macarena, Sevilla).

\section{Human, material, technological, and organizational resources}

The TMJ unit is constituted by 2 maxillofacial surgeons with part-time dedication who perform the related functions of care, management, and training.

The specialized care unit will be equipped with a highcapacity computer terminal (Office-XP for Windows XP, PGP encryption software, and an electronic mail account of the SAS Corporate Intranet Network), printer, and telephone terminal (a telephone number for resolving primacy care problems will be set up).

The primary care center using the teleconsultation service will be equipped with computers and conventional software (Microsoft and Word Outlook). Each primary care center has an electronic mail account in the same corporate network.

The communication channel is supported by a heterogeneous system of asynchronous transfer mode networks (ATM) and integrated service digital network (ISDN) with a suitable bandwidth for the type of data that are going to be transmitted (now existent).

\section{Diagnostic effectiveness and quality control. Cost-effectiveness analysis}

An important aspect of developing of new diagnostic techniques is to evaluate the operation and the benefits of the new methodology. Although some teleconsultation studies exist in our specialty, ours is the first using a deferred or asynchronous telemedicine system, which is why literature citations on quality control measures and diagnostic effectiveness are not applicable to our project. The diagnostic effectiveness and quality control of the TMJ Unit will be evaluated by means of:

A. Effectiveness and diagnostic accuracy of the clinical questionnaire and radiographic images, including the rate of detection of relevant processes, precision, accuracy, and tasa de concordancia clínica y radiológica entre los dos cirujanos maxilofaciales. 
B. Valorar la teleconsulta como medio de cribado o selección de pacientes con patología quirúrgica de la ATM: valoraremos la tasa de consultas de ATM resueltas en Atención Primaria, la tasa de peticiones de patología de ATM enviadas a la consulta física de atención especializada y, de ellas, la tasa que precisarán tratamiento quirúrgico. Igualmente se cuantificarán el número de peticiones de teleconsulta de pacientes en los que ha fracasado el tratamiento de AP y precisan de una nueva valoración y tratamiento en la consulta física.

C. Satisfacción de los médicos usuarios, pacientes, y cirujanos maxilofaciales: Se medirá mediante encuestas la satisfacción.

D. Satisfacción de la administración hospitalaria que será valorada mediante encuestas de satisfacción, diferencia entre el número de derivaciones desde AP en patología de la ATM antes y después de la instauración de la teleconsulta, estudio de demoras (demora máxima de $1^{\mathrm{a}}$ consulta, demora máxima de $2^{\mathrm{a}}$ consulta), agilización en la asistencia especializada en patologías más graves, desarrollo de nuevas tecnologías.

En cuanto al análisis del coste-efectividad, se cuantificará el número de pacientes asistidos por este nuevo sistema, tanto de aqueIlos que van a ser tratados en AP como aquellos que son derivados a la consulta física de ATM en el hospital. El coste fundamental para la administración se dirigirá al acondicionamiento de la consulta ATM con un equipo PC de alta capacidad. Una vez puesto en funcionamiento el sistema de teleconsulta, la asistencia a través de Internet es más económica que la consulta tradicional, y además de evitar desplazamientos desde zonas lejanas al hospital se reducirá de forma considerable el volumen de primeras visitas y revisiones en nuestras consultas externas.

\section{Confidencialidad y protección de datos}

El capítulo de la confidencialidad y protección de los datos transmitidos a través de Internet es uno de los puntos más conflictivos de la telemedicina en cuanto a implicaciones legales se refiere. Según la Ley Orgánica de Protección de Datos de Carácter Personal (15/1999) y las directrices comunitarias sobre protección de datos (95/46 CE, 96/9 CE, 97/66 CE) si se consigue respetar el anonimato de los pacientes el uso de la telemedicina no tiene por qué plantear ningún problema jurídico. Por ello, estableceremos una cuádruple vía de protección del anonimato del paciente y de toda la información clínica transmitida: en primer lugar las peticiones de teleconsulta están encabezadas e identificadas mediante el NUHSA sin identificar los datos personales de los pacientes; en segundo lugar se utilizará un software de encriptación PGP, mediante el reparto de claves públicas y privadas entre los terminales conectados; en tercer lugar, la transmisión de datos se realizará a través de la Red Intranet Corporativa del Servicio Andaluz de Salud, lo que proporciona un sistema de seguridad intrínseco al canal de comunicación, en tanto que se trata de una red de direccionamiento IP interno no enrutable, con filtros para determinados protocolos y como cuarta vía se restringirá el acceso a los terminales mediante claves personales. intrapersonal and interpersonal clinical-radiological agreement between primary and specialized care. The rate of clinical and radiological agreement between the two maxillofacial surgeons will be established.

B. To assess teleconsultation as a tool for screening or selecting patients with surgical TMJ pathology: we will assess the percentage of TMJ consultations resolved in primary care, the number of TMJ pathology requests submitted to the physical TMJ Unit and how many require surgical treatment. We will log the number of teleconsultation requests from patients in which primary care treatment has failed and they need re-evaluation and treatment in the physical TMJ Unit.

C. Satisfaction of physician users, patients, and maxillofacial surgeons: This will be measured by satisfaction surveys.

D. The satisfaction of hospital management will be evaluated by satisfaction surveys, the difference between the number of referrals from primary care for TMJ pathology before and after introducing teleconsultation, study of delays (maximum delay for first consultation, maximum delay for second consultation), streamlining of specialist care in more serious pathologies, and development of new technologies.

Cost-effectiveness analysis will be conducted by quantifying the number of patients assisted using this new system, including those treated in primary care and those referred to the hospital TMJ Unit. The main cost of management will be equipping the TMJ Unit with a high-capacity computer. Once the teleconsultation system is in operation, care through the internet is less expensive than the traditional visit. In addition to not requiring travel from distant areas to the hospital, it will considerably reduce the volume of first visits and follow-up in our outpatient clinics.

\section{Confidentiality and data protection}

Confidentiality and the protection of data transmitted through the Internet are one of the most controversial points of telemedicine in terms of its legal implications. According to the statutory law on the protection of information of a personal nature (15/1999) and Community directives on data protection (95/46 CE, 96/9 CE, 97/66 CE), as long as the anonymity of patients is safeguarded during telemedicine use, there should be no legal problems. For that reason, we have established four layers of protection of patients anonymity and all clinical information transmitted: firstly, teleconsultation requests are labeled with the NUHSA and no personal information of patients; secondly, PGP encryption software will be used and public and private passwords will be distributed among the terminals connected; thirdly, data transmission will be through the Corporate Intranet Network of the Andalusian Health Service, which is equipped with a security system for the communication channel, con- 


\section{Conclusiones}

Si bien nuestra experiencia en el terreno de la telemedicina es corta, la efusiva acogida por parte de todos los usuarios del sistema, desde la administración que ve una forma rápida y segura de optimizar recursos ya existentes y de mejorar la asistencia de los pacientes, a los odontólogos de atención primaria que adquieren una nueva herramienta de trabajo que le acerca al especialista, nos hace ser optimistas en cuanto a la consecución de los objetivos que nos hemos marcado. No obstante somos conscientes que un proyecto tan innovador y de tanta envergadura como el que pretendemos desarrollar en nuestro servicio, no va a estar exento de dificultades, y que va a suponer un esfuerzo importante por parte de todos los integrantes del mismo.

\section{Bibliografía}

1. Prieto I, Prieto A, Bascones A. Cáncer oral. Med Clin (Barc) 2006;127:258-64.

2. Lerch IA. Progress in telemedicina. En: Bajzer Z, Baxa P, Franconi $C$, editors. Proceedings of the II Internacional Conference On Applications of physics to Medicine and Biology. Singapore: World Scientific Publishing, 1983;435-78.

3. Paoli JR, Barthelemy I, Lauwers F, Boutault F, Fabie M. The internet in oral medicine and maxillofacial surgery. Rev Stomatol Chir Maxillofac 1996;97:202-8.

4. Rollert MK, Strauss RA, Abubaker AO, Hampton C. Telemedicina consultations in Oral and Maxillofacial Surgery. J Oral Maxillofac Surg 1999;57:136.

5. Roccia F, Spada MC, Milani B, Berrote S. Telemedicina in maxillofacial trauma: a 2-year clinical experience. J Oral Maxillofac Surg 2005;63:1101-5.

6. Jacobs MJE, Edmondson MJ, Lowry JC. Accuracy of diagnosis of fractures by maxillofacial and accident and emergency doctors using plain radiography compared with a telemedicine system: a prospective study. $\mathrm{Br}$ J Oral Maxillofac surg 2002;40:156.

7. Ewers R, Schicho K, Wagner A, Undt G, Seeman R, Figl M, Truppe M. Seven years of clinical experience with teleconsultation in craneomaxillofacial surgery. J Oral Maxillofac Surg 2005;63:1447-54.

8. Moreno D, Pérez AM, Ferrándiz L, Carrasco R, Serrano P, Camacho F. Teleconsulta de lesiones pigmentadas. Piel 2004;19:472-9. sisting of a network of internal non-routable IP addresses with filters for certain protocols, and fourthly, access to terminals will be restricted by personal passwords.

\section{Conclusions}

Although our experience in the area of telemedicine is brief, it has received and effusive welcome from all system users. Management views it as a fast and safe way of optimizing existing resources and improving patient care and primary care odontologists are pleased to have a new tool for approaching specialists, which makes us optimistic about achieving the goals that we have set. Nevertheless, we are aware that a project as innovative and ambitious as the one that we are trying to develop in our department will not be free of difficulties and will require a major effort by all participants. 